\title{
THE USE OF ENVIRONMENTAL INDICATORS BASED ON THE AIR QUALITY INDEX, AS TOOL FOR THE ESTABLISHMENT OF PUBLIC POLITICS
}

\section{O USO DE INDICADORES AMBIENTAIS BASEADOS NO ÍNDICE DE QUALIDADE DO AR, COMO FERRAMENTA PARA O ESTABELECIMENTO DE POLÍTICAS PÚBLICAS.}

\author{
Rita de Cássia Modesto Anizelli \\ ritanizelli@yahoo.com.br \\ Josimar Ribeiro de Almeida \\ jralmeida@usp.br \\ Observatório Urbano/UERJ/UN-Habitat \\ Gustavo Aveiro Lins \\ gu.lins@terra.com.br \\ CEDERJ/SEE-RJ/CEDAE \\ Manoel Gonçalves Rodrigues \\ manoel.grodrigues@gmail.com \\ Observatório Urbano/UERJ/UN-Habitat
}

\begin{abstract}
Betim, integral city of the MRBH - Metropolitan Region of Belo Horizonte, counts with a net of Air Quality Monitoring, consisting of four manual stations operated by the Siderúrgica Metalsider Ltda. Enterprise which monitor Particulate Material, being three the stations which monitor TPS (Total Particles in Suspension) and one which monitors IP (Inhalable Particles) parameter, installed since 2005 with the start of operation in February, except the Cachoeira Station operating since October 2005.The results are converted by the methodology AirQI (Air Quality Index) developed by USEPA to legally define an upper limit for the concentration of an atmospheric component that, if exceeded, could cause pollution or environmental degradation. The quality indexes for TPS (Total Particles in Suspension) were inadequate in Santa Cruz Station, 2, 6 and 2 times respectively in 2006, 2007 and 2008 with concentrations of 232,302 and $268 \mu \mathrm{g} / \mathrm{m}^{3}$ and no one in the Cachoeira Station, this effectively under the influence of the monitored company, with maximum concentrations of 122, 205 and $167 \mu \mathrm{g} / \mathrm{m}^{3}$. In the Central Station, the quality was Inadequate once in 2007 and other time in 2008 for IP. Valid values obtained for the air quality indexes in Betim are resulted from the Inhalable Particles concentrations (PM-10) in Central Station - CEABE which were 122.205 and $167 \mu \mathrm{g} / \mathrm{m}^{3}$ from 2006 to 2008. The annual standard allowed by Law which is $50 \mathrm{~g} / \mathrm{m}^{3}$.
\end{abstract}

Keywords: monitoring, air quality index, particulate material, inhalable particles, Betim metropolitan region of Belo Horizonte. 


\section{RESUMO}

Betim, cidade integrante da RMBH - Região Metropolitana de Belo Horizonte conta com uma rede de Monitoramento da Qualidade do Ar, constituída por quatro estações manuais operadas pela empresa Siderúrgica Metalsider Ltda. que monitoram Material Particulado, sendo três as estações que monitoram PTS (Partículas Totais em Suspensão) e uma que monitora o parâmetro PI (Partículas Inaláveis). Instaladas desde 2005 com inicio de operação em fevereiro, exceção feita à estação cachoeira que opera desde outubro de 2005. Os resultados são convertidos pela a metodologia, IQAr (Índice de Qualidade do Ar) desenvolvida pela USEPA para definir legalmente um limite máximo para a concentração de um componente atmosférico que, se ultrapassado, poderá causar poluição ou degradação ambiental. Os índices de qualidade para PTS foram inadequados na estação Santa Cruz, 2, 6 e 2 vezes respectivamente em 2006, 2007 e 2008 com concentrações de 232,302 e 268 $\mu \mathrm{g} / \mathrm{m}^{3}$ e nenhuma na estação Cachoeira, esta, efetivamente sob influência da empresa monitorada, com concentrações máximas de 122, 205 e $167 \mu \mathrm{g} / \mathrm{m}^{3}$. Na estação Centro, a qualidade foi Inadequada uma vez em 2007 e outra em 2008 para PI. Os valores válidos obtidos para os índices de qualidade do ar em Betim decorrem das concentrações de Partículas Inaláveis (PM-10) na Estação Centro - CEABE foram 122,205 e $167 \mu \mathrm{g} / \mathrm{m}^{3}$ para os anos de 2006 a 2008 O padrão anual permitido pela Lei que é 50,0g/m3.

Palavras-chave: monitoramento, índice de qualidade do ar, material particulado partículas inaláveis, Betim região metropolitana de Belo Horizonte.

\section{INTRODUCTION}

One contemporary challenge attached to the several areas of knowledge has been assessing the impacts caused by human activities on the environment and to implement them as an especially public management tool. Ecosystems have mechanisms that operate to limit the impact of the stressor, at least to some degree (ALMEIDA and LINS, 2009)

Which are the parameters for the sum of environmental impacts in regions where projects that meet legislation will be able to install? What are the limits of agglomeration of industries for air quality perceived by neighboring populations? So, how to turn air quality indicators into indicator for Master Plans management, for example? Which parameters could be used?

This study object is to consider the air quality, converted into air quality indexes, by the current methodology resulted from different contributions and activities, and, even though, individually, suited to the current standards, as guiding principles and limiters for other activities installation, including the resulting anthropic activities, to meet the idea of sustainable development and environment preservation, with social responsibility. 
The overall objective is to determine the AirQI as auxiliary environmental management tool for environmental management including soil occupation and installation of facilities in the municipality of Betim, through the conversion of the results of air quality monitoring conducted in Betim as the PM-10 IP parameters into air quality indexes as a tool for administrative decision to support decision of enterprise leasing in areas covered by the monitoring manual stations of the municipality of Betim-MG. Incidentally, evaluate and check the trends and changes of the found indexes and the obtained indexes by confronting them with the relevant environmental legislation and make proposals so that the air quality monitoring can be adopted as a tool for the local environmental management.

Air quality became one of the biggest concerns in this turn of the century. Air pollution is meant as the change in its composition or its properties, due to the emission of pollutants by several agents, natural or artificial source. (COELHO,1977:156-157).

AYOADE (1998: 309) alerts that the pollution of air affects the climate of the urban areas through diverse forms. The proper energetic balance in cities suffers interference, because the pollutants reflect, disperse and absorb solar radiation. Many pollutants also serve as condensation nuclei, being therefore abundant in cities, which air humidity is already substantially fueled through evaporation, industrial processes and of cars, which emit large amounts of water vapor. Consequently, the trend of the precipitation is to increase on the urban areas. However, the most alarming effects of the atmospheric pollution occur in the health of the urban population.

Air pollution actually became to be considered a problem linked to public health from the Industrial Revolution, which led to the gradual loss of air quality in urban-industrial centers, with sharp reflexes on health and no longer a wellness problem and came to represent a risk to the population effectively (AYOADE, 1998: 312). Population increasing in the twentieth century on urban centers and the intensive and growing vehicle usage caused the critical episodes of air pollution and the victims report to be more frequent.

The search for a solution must count with various sectors of society and administrative spheres, both national and international level (AYOADE, 1988), while social aspects aggravate the already intricate existing technical background to the use of data on air pollution, in addition to the local variables such as spatial 
distribution, the urban site, demographic density, urban and transport functions (CERQUEIRA, 2000).

The use of particulate material monitoring data should not only guide the enterprises in their management policies, but also serve to health policies, taking into consideration the seasonal rainy periods and the consequent possibility of critical episodes that the methodology generalizes. In the preventive field, the implementation of recommendations and even the occupation restrictions which have the potential to worsen air quality for neighboring populations, although they comply with the applicable emission standards, are administrative responsibility for municipal authorities in their decision-making process.

\section{ATMOSPHERIC POLLUTION}

The Air Quality Index (AirQ) has as main objective to provide the population with understanding about the local air quality, related to diverse atmospheric pollutants sampled at the monitoring stations and disseminated by a twenty-four-hour air quality bulletin.

The Air Quality Index is a mathematical tool used to transform the measure concentrations of diverse pollutants into a single dimensionless value that enables the comparison with the legal limits of concentration for diverse Standards of Air Quality (SAirQ) pollutants, value obtained through a segmented linear function, where the inflection points represent the National Standards of Air Quality and the criteria for fierce air pollution episodes established according to CONAMA Resolution no. 03 of June 28th, 1990, for: Total Suspended Particles, Inhalable Particles and Sulfur Dioxide, Nitrogen Dioxide, Ozone and Carbon Monoxide.

The AirQI can also be associated to the effects of air pollution on human health. The overtaking of the National Standards of Air Quality for more than one pollutant, in the same station, all will be divulged, identified for the INADEQUATE quality (AirQI bigger than 100). The BAD quality (bigger AirQI that 200) indicates the overtaking of the Level of Attention, WORSE quality indicates the overtaking of the Alert Level of and the CRITICAL quality, the overtaking of the Level of Emergency. (Table 1; Table 2) 
Table 1 - Air Quality Index (AirQI)

\begin{tabular}{|c|c|c|c|c|c|c|c|c|}
\hline Quality & Index & $\begin{array}{l}\text { Levels of } \\
\text { caution } \\
\text { on health }\end{array}$ & $\begin{array}{c}\text { PTS } \\
\left(\mu \mathrm{g} / \mathrm{m}^{3}\right)\end{array}$ & $\begin{array}{c}\text { Pl10 } \\
\left(\mu \mathrm{g} / \mathrm{m}^{3}\right)\end{array}$ & $\underset{\left(\mu \mathrm{g} / \mathrm{m}^{3}\right)}{\mathrm{S} 2}$ & $\begin{array}{c}\mathrm{NO2} \\
\left(\mu \mathrm{g} / \mathrm{m}^{3}\right)\end{array}$ & $\begin{array}{c}\mathrm{CO} \\
(\mathrm{PPm})\end{array}$ & $\begin{array}{c}03 \\
\left(\mu \mathrm{g} / \mathrm{m}^{3}\right)\end{array}$ \\
\hline good & $0-50$ & & $0-80$ & $0-50$ & $0-80$ & $0-100$ & $0-4,5$ & $0-80$ \\
\hline regular & $51-100$ & & $81-240$ & $51-150$ & $81-365$ & $101-320$ & $4,6-9,0$ & $81-160$ \\
\hline inappropriate & $\begin{array}{c}101- \\
199\end{array}$ & $\begin{array}{l}\text { Unhealthy for } \\
\text { Sensitive } \\
\text { Groups }\end{array}$ & $\begin{array}{l}241- \\
375^{\star}\end{array}$ & $\begin{array}{l}151- \\
250^{*}\end{array}$ & $\begin{array}{c}366-586^{*} \\
587-800\end{array}$ & $\begin{array}{c}321- \\
1130^{*}\end{array}$ & $\begin{array}{c}9,1-12,4^{\star} \\
12,5- \\
15,0\end{array}$ & $\begin{array}{c}161-322^{*} \\
323-400\end{array}$ \\
\hline bad & $\begin{array}{l}200- \\
299\end{array}$ & Very unhealthy & $376-625$ & $\begin{array}{c}251-350 \\
351- \\
420^{\star}\end{array}$ & $801-1600$ & $\begin{array}{l}1131- \\
2260\end{array}$ & $15,1-30$ & $401-800$ \\
\hline terrible & $\begin{array}{l}300- \\
399\end{array}$ & dangerous & 626-875 & $421-500$ & $\begin{array}{l}1601- \\
2100\end{array}$ & $\begin{array}{l}2261- \\
3000\end{array}$ & $30,1-40$ & $801-1000$ \\
\hline criticism & $\begin{array}{l}\text { Acima } \\
\text { de } 400\end{array}$ & Very dangerous & $>876$ & $>500$ & $>2100$ & $>3000$ & $>40$ & $>1001$ \\
\hline
\end{tabular}

Source: www.fepam.rs.gov.br/qualidade

Obs.: The indexes until the REGULAR classification, meet the Standards of Air Quality, established by CONAMA Resolution 03 of June $28^{\text {th }}, 1990$.

The CONAMA establishes National Standards of Air Quality, through the Resolution $n^{\circ}$. 03 of June $28^{\text {th }}, 1990$. An air quality standard sets the maximum legally for the concentration of a pollutant that guarantees the protection of the health and well-being of the population in General. The established standards are divided in two types:

a. Primary standards of air quality are the pollutants concentrations that if overtaken can affect population health. They can be understood as maximum tolerable levels of atmospheric pollutants concentration, constituting short and longterm goals.

b. Secondary Standards of air quality are atmospheric pollutants concentrations below of what is predictable as an adverse minimum effect over the population wellbeing, as well as the minimum harzard to fauna and flora, materials and general environment. They can be understood as desirable levels of pollutants concentration, constituting a long term goal. The atmospheric pollutants regulated by CONAMA are presented by following. 
Table 2 - National Standards of Air Quality - CONAMA Resolution n. 03 of June $28^{\text {th }}$, 1990.

\begin{tabular}{|c|c|c|c|c|}
\hline Pollutant & sampling time & $\begin{array}{c}\text { primary standard } \\
\mu \mathrm{g} / \mathrm{m}^{3}\end{array}$ & $\begin{array}{c}\text { secondary standard } \\
\mu \mathrm{gg} / \mathrm{m}^{3}\end{array}$ & $\underset{\star \star}{\text { measurement method }}$ \\
\hline \multirow{2}{*}{ PTS } & 24 hour $^{*}$ & 240 & 150 & \multirow{2}{*}{$\begin{array}{c}\text { Amostrador de Grandes } \\
\text { Volumes }\end{array}$} \\
\hline & $\mathrm{MGA}^{* *}$ & 80 & 60 & \\
\hline \multirow{2}{*}{ PI } & 24 hour * & 150 & 150 & \multirow{2}{*}{$\begin{array}{c}\text { Separação } \\
\text { Inercial/Filtração }\end{array}$} \\
\hline & $\mathrm{MAA}^{* * *}$ & 50 & 50 & \\
\hline \multirow{2}{*}{ Smoke } & 24 hour * & 150 & 100 & \multirow{2}{*}{ Refletância } \\
\hline & $\mathrm{MAA}^{* * *}$ & 60 & 40 & \\
\hline \multirow{2}{*}{$\mathrm{SO}_{2}$} & 24 hour * & 365 & 100 & \multirow{2}{*}{ Pararrosanilina } \\
\hline & $\mathrm{MAA}^{* * *}$ & 80 & 40 & \\
\hline \multirow{2}{*}{$\mathrm{NO}_{2}$} & 1 hour * & 320 & 190 & \multirow{2}{*}{ Quimiluminescência } \\
\hline & MAA $^{* * *}$ & 100 & 100 & \\
\hline \multirow{4}{*}{ CO } & \multirow{2}{*}{1 hour * } & 40.000 & 40.000 & \multirow{4}{*}{$\begin{array}{l}\text { Infravermelho não } \\
\text { Dispersivo }\end{array}$} \\
\hline & & $35 \mathrm{ppm}$ & $35 \mathrm{ppm}$ & \\
\hline & \multirow{2}{*}{8 hour * } & 10.000 & 10.000 & \\
\hline & & $9 \mathrm{ppm}$ & $9 \mathrm{ppm}$ & \\
\hline $\mathrm{O}_{3}$ & 1 hour * & 160 & 160 & Quimiluminescência \\
\hline
\end{tabular}

Source: www.sema.gov.br

PTS - Total suspended particles

$\mathrm{PI}$ - Inhalable Particles

Should not be exceeded more than once per year.

${ }^{* *}$ Annual geometric average.

${ }^{* * *}$ Annual arithmetic average.

**** The resolution allows the use of equivalente method.

This resolution establishes yet critical air pollution episode when observed the presence of high concentrations of pollutants in the atmosphere in short period of time, resulting from the occurrence of weather conditions unfavorable to their dispersion. The Attention, Alert and Emergence Levels for different refereed values are established. In consensus with the international conventions, the Brazilian legislation adopts limits for emissions of certain pollutants whereas the known effects and sources.

Considering TPS and IP, the sources are solid or liquid material particles that are suspended in the air, in the form of dust, mist, spray, smoke, soot, upper or lower sized to 100 microns and are coming from industrial processes, motor vehicles (exhaustion), re-suspended road dust, burning of biomass or secondary aerosol 
(formed in the atmosphere).

The conversion of concentrations found in monitoring air quality, converted into air quality indexes aim to inform and expedite the measures to be taken for the protection of the population in critical episodes about the effects on health and on the environment already known:

The basic legal framework, in term of Law 6938/81 of August 1st, 1981, for combat, prevention and control of atmospheric pollution is governed by CONAMA Resolution $\mathrm{n}^{\circ}$. 05/89, June $15^{\text {th }} 1989$, which instituted the Programa Nacional de Controle da Qualidade do AR (PRONAR). Among the various resolutions the CONAMA resolution $03 / 90$ of June $28^{\text {th }}, 1990$ that guides the analysis of data generated in the campaign air quality monitoring in Betim and establishes the secondary air quality standards and reference methods for measuring air quality, as well as the criteria for acute episodes. Minas Gerais adopts the Normative Deliberation COPAM 01/81, May 26th, 1981 which provides for on the norms and standards for air quality. The air pollutants are those universally adopted and the resolution sets the primary and secondary standards for air quality, respectively as those that, if exceeded, may affect the health of the population and the second as the concentrations below from which it can be previewed a minimum adverse effect on the well-being of the population as well as the minimum damage to the fauna and flora and the environment in general, in short, would be desirable levels in terms of long-term goals.

The establishment of secondary patterns tries to create a basis for a policy of prevention of air quality deterioration and is applicable to preservation areas, while the primary standards are applicable to development areas and in the short term.

Table 3 - National Air Quality Standards and criteria for critical pollution episodes.

\begin{tabular}{|c|c|c|c|c|c|c|}
\hline Pollutant & $\begin{array}{c}\text { sampling } \\
\text { time }\end{array}$ & $\begin{array}{c}\text { primary } \\
\text { standard } \\
\boldsymbol{\mu g} / \mathbf{m}^{3}\end{array}$ & $\begin{array}{c}\text { secondary } \\
\text { standard } \\
\mu \mathbf{m} / \mathbf{m}^{3}\end{array}$ & $\begin{array}{c}\text { Level of care } \\
\boldsymbol{\mu g} / \mathbf{m}^{3}\end{array}$ & $\begin{array}{c}\text { Alert level } \\
\boldsymbol{\mu g} / \mathbf{m}^{3}\end{array}$ & $\begin{array}{c}\text { Emergency } \\
\text { level } \\
\boldsymbol{\mu g} / \mathbf{m}^{3}\end{array}$ \\
\hline PTS & 24 hour $^{(1)}$ & 240 & 150 & 375 & 625 & 875 \\
& MGA $^{(2)}$ & 80 & 60 & 24 hour & 24 hour & 24 hour \\
\hline PI & 24 hour $^{(1)}$ & 150 & 150 & 250 & 420 & 500 \\
& $\operatorname{MAA}^{(3)}$ & 50 & 50 & 24 hour & 24 hour & 24 hour \\
\hline
\end{tabular}

Source: CONAMA Resolution no. 03/90, June 28th, 1990.

PTS - Total suspended particles 
PI - Inhalable Particles

(1) - Should not be exceeded more than once per year.

(2) - Annual Geometric Average.

(3) - Annual Arithmetic Average.

Systematic measurement of air quality is restricted to pollutants that are defined by relevance and the availability of resources for their follow-up. (Then it was developed the methodology AirQI (air quality Index); PSI (Pollutant Standards Index) by the USEPA-United States Environmental Protection Agency) (STATE ENVIRONMENT FOUNDATION, 2001). The CONAMA and other State organs adopt the same methodology that allows the visualization of air quality via an easy-tounderstand scale, which allows organs such as the health ones, for alerts to the population about critical episodes.

The situations under intense industrial activity, resulted in the establishment of self-monitoring programs that assess the emissions in terms of concentration of pollutants in the areas under environmental influence, notably those inhabited or pair of conservation concerns about the flora, fauna and other natural resources, always focusing population well-being (BAIRD 2002). So, the program subsidizes emergency actions during periods of stagnation when the levels of atmospheric pollutants represent risk to public health and can support decisions for definition of soil occupation, especially becoming a tool for Master Plan, as well as new targets for industrial and anthropic activities. The methodology used to enhance and expand knowledge about the air quality in the municipality of Betim, Minas Gerais State, resulted in the study on the conclusions undertaken from the information contained in the database of the environmental Divisão de Licenciamento Ambiental da Secretaria Municipal de Meio Ambiente do município (SEMEIA) under the AirQI. The results of the measurements of the parameters TPS and IP presented monthly by Metalsider to Municipal Environmental Agency through reports reported to state licensing body, which includes copies of the worksheets, graphic charts of measurements and certificates of equipment calibration. It was necessary to create a database to facilitate access to information of interest to the study, such as the annual averages of concentrations of pollutants and changes in air quality indices over the years sampled, for interpreting the results obtained in the program for air quality monitoring. For this, it was used the application Microsoft Excell, 2000 version, that allows the 
manipulation of spreadsheet calculations, as well as the incorporation of graphs and maps.

A series of spreadsheets with charts, tables and frames was created for each year of monitoring and the information organized as follows:

a) The largest concentrations of pollutants in each month of the year sampled for each monitoring station.

b) Descriptive statistics of sampling campaigns.

c) Annual averages of concentrations of pollutants.

d) Number of samples taken, number of losses of sampling and the number of times that the daily air quality standard for the pollutant exceeded (Assisi, 2009).

e) Conversion of results on air quality index according to the USEPA methodology (Assisi, 2009).

Air quality standards legally define the upper limit for the concentration of a pollutant in the atmosphere, which guarantees the protection of health and environment. Air quality standards are based on scientific studies on effects produced by specific pollutants and fixed as levels that can provide an adequate safety margin.

As stipulated in the Resolution CONAMA №. 03/90, differentiated application of primary and secondary standards requires that the national territory is divided in classes I, II and III according to the intended use. The same resolution also provides that pending the establishment of the areas classification the applicable standards will be the primary.

The same Resolution also establishes the criteria for acute episodes of air pollution. The declaration of the states of Attention, Alert and Emergency requires, beyond the reached levels of concentration, the forecast of favorable meteorological conditions to the dispersion of the pollutants. In this case the State Legislation is stricter for the level of attention $(200 \mu \mathrm{g} / \mathrm{m} \mathrm{3})$.

The air quality index is a mathematical tool developed to simplify the process of dissemination of air quality. This index has been used since 1981, and was created using as a basis a long experience developed in Canada and USA. It provides precise information, quickly and easily understood about daily levels of air quality in a given region. 
The Air Quality Index (AirQl), adopted by the Conselho Nacional do Meio Ambiente (CONAMA) and State environmental agencies, was designed based on the PSI (Pollutant Standards Index) of Environmental Protection Agency (EPA) in order to standardize the disclosure of air quality by the media.

The index is obtained by a segmented linear function that relates the inflection points of the curve to the standards of air quality. Thus, the value of the concentration of the pollutant (in $\mu \mathrm{g} / \mathrm{m}^{3}$ ), determined in the laboratory sampling and analysis, is converted into an index that qualifies the atmospheric air of a particular region. The IQA converts the measured pollutant concentration to an integer in the scale of 0 to greater than 400 . The number 100 corresponds to the air quality standard established by CONAMA. If the AirQI exceeds the value of 100 means that the particular pollutant exceeded the acceptable concentration scale that day.

In its turn an AirQI with value below 100 means that the concentration of the pollutant is satisfactory.

The AirQI allows the population to know the quality of the air in relation to the level of pollution in accordance with the following scale: good, regular, inadequate, bad, very bad or critical. In addition, public institutions linked to the environment or to health may use the AirQI as a tool to alert the population and to determine the adoption of emergency measures that may become necessary if pollution levels reach hazardous values to human health. For each pollutant measured is calculated an index that results in the following structure of the air quality index.

Table 4 - Structure of the air quality index (FEAM, 2001).

\begin{tabular}{|c|c|c|c|c|}
\hline IQA & Air Quality & $\begin{array}{c}\text { Color } \\
\text { Reference }\end{array}$ & Levels of caution / Meaning \\
\hline $0-50$ & good & blue & Virtually no health risks \\
\hline $51-100$ & regular & green & $\begin{array}{r}\text { People in sensitive groups (children, the elderly and people with } \\
\text { respiratory and heart diseases), may exhibit symptoms such as dry } \\
\text { cough and tiredness. The population in general is not affected. }\end{array}$ \\
\hline $101-199$ & inappropriate & orange & $\begin{array}{r}\text { ATTENTION } \\
\text { All people may experience symptoms such as dry cough, fatigue, } \\
\text { burning eyes, nose and throat. People in sensitive groups (children, } \\
\text { the elderly and people with respiratory and heart diseases), may } \\
\text { have more serious effects on health. }\end{array}$ \\
\hline $200-299$ & bad & red & $\begin{array}{r}\text { ALERT } \\
\text { Whole population may have worsening symptoms such as dry } \\
\text { cough, fatigue, burning eyes, nose and throat and still has } \\
\text { shortness of breath and wheezing. Even more serious effects to the } \\
\text { health of sensitive groups (children, the elderly and people with } \\
\text { respiratory and heart diseases). }\end{array}$ \\
\hline
\end{tabular}




\begin{tabular}{|c|c|c|c|}
\hline $300-399$ & terrible & brown & EMERGENCY \\
\hline$>400$ & criticism & black & CRITICISM \\
\hline
\end{tabular}

Source: www.sema.gov.br

The historical analysis of the air quality index has shown that inhalable particles with aerodynamic diameter less than $10 \mu \mathrm{m}$ (PM10) and tropospheric ozone are the pollutants responsible for higher values of concentration in air ambient.

So, the methodology can be simplified and adopt only these two pollutants to the daily weather forecast on AirQI representation, in terms of maximum value of the time of $\mathrm{O}_{3}$ and daily average $\mathrm{PM} 10$.

Regardless of any factors of synergy between the different pollutants, the degree of degradation of air quality will be more dependent on the worst between the two pollutants considered.

The numeric system of air quality forecast estimates, hour by hour, the concentration of each pollutant, for each cell, of $10 \mathrm{~km} \times 10 \mathrm{~km}$, of the national territory. The maximum time of ozone and the average daily value of concentration of inhalable particles, calculated on the basis of the results of the number system for the 24 hours of the day of the forecast are evoked for index representation.

Index is determined, for each pollutant, in accordance with the previously defined classification classes.

The air quality index represented on a map of forecast corresponds to the pollutant with the worst index (FEAM, 2009).

\section{MEASUREMENTS}

The monitoring network in Betim has been operated since February and October 2005 by Metalsider Steel Ltda, in compliance to the environmental licensing conditions established by FEAM.

There are four manual stations that operate the monitoring program according to guidelines of the program for monitoring the air quality around the FEAM Ventures, and in three of them the measurement performed is only a TPS parameter and only one responsible for measurement of IP.

Although the environmental agency of the Secretaria Municipal de Meio Ambiente (SEMEIA) is not responsible for the environmental licensing of Metalsider, 
the company forwards a copy of the report of air quality monitoring for the follow-up of this organ every month. Then it was created a database the Divisão de Licenciamento Ambiental of SEMEIA with the results of the measurements.

The monitoring program was implemented in accordance with the guidelines for the Programa de Monitoramento da Qualidade do $\operatorname{Ar}$ no Entorno de Empreedimentos of FEAM (ASSIS, 2009).

The equipment manuals, high-volume Sampler PM-10 and large volume $\mathrm{Hi}$ vol Sampler were installed and the sampling frequency adopted was of every six days, recommended by the USEPA - Environmental Protection Agency-United States Government to give greater data representation: with the weekly variation in relation to the regular day of the week that the samples were performed.

The representation data criteria were from CETESB (Companhia Tecnologia de Saneamento Ambiental/São Paulo): $75 \%$ (seventy five percent) of the daily sampling for each semester and $75 \%$ (seventy five percent) for each month (CETESB, 2003).

The net was established in 2005 and remains in operation, however to obey the pertinent methodology, the data of the years of 2006 to 2008 will be the only one object of this study regarding continuity of the evaluation of the quality of air on the basis of the legal standards established to protect the health and the welfare of the people.

The analysis of data generated must be easy-to-view and to make possible, in the end, guidelines or goals that can be implemented by area managers, in order to achieve sustainable development. For this, graphics that demonstrate what the current situation of the company in relation to environmental indicators established will be used and from this evaluation, be able to establish a plan of action to achieve sustainable development proposed at work, making the approach of quantitative and qualitative research.

And to meet the considered objective the research pointed survey of the available methods of economic valuation of the environment; survey of the generated ambient impacts in the company in study; economic evaluation evidencing the sustainability of the company; analysis of economic viability of the environment cost and benefit; evaluation of the information for the estimate of the ambient valuation, verifying in the raised data; evaluation of the relevance of the pointers considered as for the sustainability and demonstrative of the profitability of the company in study to 
be ambiently sustainable and keep itself competitive in the market.

\section{RESULTS AND DISCUSSIONS}

The Santa Cruz Station monitoring of TPS as well as parameter of the Monitoring PM-10 Centre Station had its beginning in February 2005, while the Linesmen and Waterfall Stations had their activities begun in October of the same year. The fact makes impracticable the analysis of the data via the media annual pollutant concentrations or the number of samplings performed, the statistical representativity, given the number of losses of sampling and the actual number of times the daily air quality standard for the pollutant was exceeded. However, in terms of the establishment of the AirQl and its use, it is possible to consider the data, as well as ongoing campaigns in 2009. The option established here prioritized the campaigns carried through from 2006 to 2008. The data are presented in Table 5.

Table 5 - Data obtained in the sampling program

\begin{tabular}{|c|c|c|c|c|c|c|c|c|c|c|c|c|}
\hline \multirow[b]{2}{*}{ Stations } & \multicolumn{4}{|c|}{2006} & \multicolumn{4}{|c|}{2007} & \multicolumn{4}{|c|}{2008} \\
\hline & ST & EC & CA & BA & ST & EC & CA & BA & ST & EC & CA & BA \\
\hline Sample Number & 60 & 60 & 60 & 60 & 60 & 60 & 60 & 60 & 60 & 60 & 60 & 60 \\
\hline $\begin{array}{l}\text { statistical } \\
\text { representativeness }\end{array}$ & Sim & Sim & Sim & Sim & Sim & Sim & Sim & Sim & Sim & Sim & Sim & Sim \\
\hline $\begin{array}{l}\text { Minimum Concentration } \\
\left(\mu \mathrm{g} / \mathrm{m}^{3}\right)\end{array}$ & 40 & 20 & 28 & 26 & 18 & 14 & 14 & 14 & 12 & 18 & 14 & 18 \\
\hline $\begin{array}{l}\text { Maximum Concentration } \\
\qquad\left(\mu \mathrm{g} / \mathrm{m}^{3}\right)\end{array}$ & 274 & 148 & 122 & 232 & 342 & 200 & 205 & 302 & 346 & 152 & 167 & 268 \\
\hline Number of exceedances & 2 & 0 & 0 & 0 & 6 & 1 & 0 & 5 & 2 & 1 & 0 & 4 \\
\hline $\begin{array}{l}\text { Average annual geometric } \\
\qquad\left(\mu \mathrm{g} / \mathrm{m}^{3}\right)\end{array}$ & 92,3 & 66 & 58,2 & 87 & 112,8 & 63,9 & 63,6 & 94,9 & 92,1 & 62,7 & 67,0 & 91,2 \\
\hline $\begin{array}{l}\text { Number of IQAr } \\
\text { Inappropriate }\end{array}$ & 2 & 0 & 0 & 0 & 6 & 1 & 0 & 0 & 2 & 1 & 0 & 0 \\
\hline
\end{tabular}

Source: Data obtained in the sampling program.

\footnotetext{
ST - Estação Santa Cruz

EC - Estação Centro

CA - Estação Cachoeira

BA - Estação Bandeirantes
} 


\section{CONCLUSIONS}

The results of the of the quality of air monitoring in Betim, in the region covered by the manual stations Metalsider in the considered period, must be seen considering its recognized limitations, determined for some decisive factors.

Knowing these factors, there is a fundamental question for reliability in data monitoring program, refeering to the statistical representativeness. The adoption of criteria for representativeness of data is of the utmost importance in monitoring systems.

In accordance with the Report of quality of air in the State of São Paulo 2002, the lack of attendance to the criteria of representation of data of one determined station, in one determined period, means that the imperfections of occured measurements significantly compromise the obtained result (REPORT OF THE QUALITY OF AIR IN THE STATE OF São Paulo, 2002).

In addition, due to being a monitoring with the use of equipment manuals, the frequency adopted for sampling was that recommended by the EPA-Environmental Protection Agency - United States Government (EPA, 2009).

Thus, the first factor is represented by the insufficient number of stations to portray the conditions of atmospheric pollution of an industrialized city, of great territorial dimension, under influences of atmospheric emissions received from the $\mathrm{RMBH}$, cut by BR 381 and 362 and subjects to passes through it of good part of the third bigger fleet of the country. Whereas, the investment in rationalisation of transport projects and transit from 2001 have made possible the improvement recorded in the studies of $\mathrm{RMBH}$, given the period of this program, it has already been internalized to this study. There is, however, an indication that there is an improvement over the years.

Then, it should be considered the prevailing wind direction that carries the pollution of the capital that although does not have any very intense industrial activity as Contagem, carries the pollution of these municipalities partially to Betim city.

The second refers to the gap due to missing data that undermine the representativeness of results and makes impracticable the accuracy of the analysis.

The representativeness of the network would be considerably higher if your data were considered with appropriate methodological adjustments and 
considerations inherent to different technologies and, in conjunction with the automatic network of Petrobras.

In general, sampling stations, concentrations of TPS and IP varied according to the same trend, according to the annual period under consideration; in the dry period amounted concentrations, while, in other periods, remained at lower levels, portraying the typical behavior of air pollution according to the climatic conditions and meteorological characteristics of the seasons. This fact also attests to the consistency of the data obtained in the monitoring program. The analysis of data obtained in the campaigns of 2006 to 2008 in all seasons, indicates that the air quality is not in accordance with the law.

Daily patterns that should not be exceeded more than once per year and the daily average of 240 to TPS, established by legislation in force, were exceeded repeatedly in the Bandeirinhas and Santa Cruz Stations. It is verified that there were no improvements in air quality over the years (ASSIS, 2009).

From 2006 to 2008 a total of 2 events were accounted where air quality is inadequate in the Center Station and of 10 events in Santa Cruz-Betim Station, with high occurrence of "Regular" in the two municipalities. Contagem and Betim are important industrial poles of the State and, in addition, are recipients of the air pollution in the capital. These factors, added to the location of stations on high-traffic regions, justify higher levels of air pollution recorded in these two municipalities. From 2001, the investment in rationalization of transport projects and transit explains the observed improvement in the air quality of Belo Horizonte and Contagem.

According to the manual of environmental impacts of the Banco do Nordeste (1999), the recommendations for industries of threads deployed in Betim mitigate the sources of atmospheric emissions, being the enterprises responsibility the minimization of the generation of atmospheric emissions using control equipment, which in turn are devices designed to remove pollutants before they are released into the atmosphere.

Also DERÍSIO (2000, p. 122), recommends that companies should also consider the use of raw materials and low pollution potential fuels; the process change for those with lower emission of pollutants; the proper maintenance and operation of the equipment and processes; and the use of appropriate layout. It is for entrepreneurs to assess the best technologies available practices for the control of these emissions, as well as the efficiency of monitoring systems. 
In Minas Gerais, the use of automatic air quality monitoring was made possible through the investment in compliance with the determinations of the COPAM and Prosecutors. This form to comply with the article "the air quality monitoring is States' role" has been disabled when the fact that the transfer of undertaking responsible for maintenance and operation of the stations to enterprises is considered. The high rate of "Missing" data presented in historical series, resulting from frequent interruptions or generation of invalid data, depicts this situation. Therefore it is necessary that the State environmental agency, not only direct financial resources to provide preventive and corrective maintenance of stations, as well as invest in the training of human resources for the operation of the network since it is its, not enterprises', the commitment to provide with regularity and reliability, information on air quality to the population.

Several factors add up and result in the worsening of air pollution in the city, highlighting the increasing vehicle fleet and the maintenance of older vehicles that generate considerable amounts of particulate materials, regardless of the implementation of the policy of metropolitan Diesel.

The proactive policies of companies, motivated by essentially economic reasons even though broadcast as environmentally friendly, it is imperative that there is continuity of the monitoring programs of air quality, preserving the historical data series on air pollution and allowing to assess the evolution and improvements effectively arising from measures implemented. The continuity of programs, since guaranteed the representativeness and implemented new stations and other monitoring parameters, will allow the monitoring of changes in air quality, as well as trends arising from changes in emissions of pollutants, adding activities, urban interventions and population growth.

Above all, the conversion of the data obtained by the Programa de Monitoramento da Qualidade do Ar must be widely disseminated by the municipal environmental agency, with the aim of providing the public and other organs, especially the health and urban management, with an easy-to-understand language to quickly provide measures that result not only in compliance with the laws, but substantially in improving the population life quality.

Other recommendations that environmental agencies can take to improve air quality and focus efforts to reduce the sources of emissions of particulate material into the atmosphere, are: 
Incorporate in the same database, other monitoring campaigns such as the one held with automatic stations by Petrobras-REGAP, whose monitoring covers other parameters, continuously in strategically arranged in the urban grid stations and account, regardless of problems specific to automatic stations of a significant historical database.

An inventory of sources of atmospheric emissions could allow the lifting of fixed and mobile sources of the municipality. And from it you can develop an atmospheric dispersion model.

Chemical analyses of materials collected in the filters of the air quality monitoring will be a means of identifying the main pollutant sources.

Providing data for land-use planning, urban planning and transport system will be useful in controlling pollution. I will enable banning of industry types in certain areas; limit the number of sources depending on the emission standards and air quantity; and enable the implementation of sanitary protection areas - green belt (DERÍSIO, 2000).

The development of studies, in conjunction with the Secretaria Municipal de Saúde, can survey the epidemiological data on the incidence of respiratory disease in susceptible populations of the regions of the city more committed to air pollution (ASSIS, 2009).

Essentially, the conversion of the results of air quality monitoring in Quality Indexes and, duly made available, especially in far-reaching media and penetration, enable, not only effective courses of action for surveillance, in pressure/reply as are also of clear understanding for the population, which contributes to effective environmental awareness, whereas she, in the last analysis is not only that object of the different effects of pollution but also her agent, given the generator human activities.

\section{REFERÊNCE BIBLIOGRAPHY}

ALMEIDA, J.R.; LINS, G.A. Caracterização Estatística de Recurso Hídrico do

Domínio Tropical Atlântico. Revista Brasileira de Pesquisa e Desenvolvimento. Volume 10, numero 2, pg. 68-75. 2009. 
ASSIS, C. M. Monitoramento da Qualidade do Ar em Betim por meio de medições manuais de Partículas Totais em Suspensão e Partículas Inaláveis. 2009.

ASSIS, C. M.; SILVEIRA, I. L.; ANIZELLI, R. C. M. Automonitoramento da qualidade do ar em Ouro Preto/M.G. Belo Horizonte, FEAM, 2003.

AYOADE, J. O. Introdução à climatologia para os trópicos. Rio de Janeiro: Bertrand Brasil, 1998. 332 p.

BAIRD, C. Química ambiental. 2 ed. Porto Alegre: Bookman, 2002.

BANCO DO NORDESTE. Manual de impactos ambientais: orientações básicas sobre aspectos ambientais de atividades produtivas. Fortaleza: Banco Mundial, 1999. 297p.

BRASIL. CONSELHO NACIONAL DE MEIO AMBIENTE. RESOLUÇÃO - CONAMA n. 03.28 jun. 1990. Estabelece padrões de qualidade do ar, métodos de qualidade do ar, métodos de amostragem e análise dos poluentes atmosféricos. Diário Oficial da União da República Federativa do Brasil, Brasília, DF, 22 ago.1990.

CAVALHEIRO, F. Urbanização e alterações ambientais. In: TAUKA, S. M. (org.). Análise ambiental: uma visão multidisciplinar. São Paulo: Editora da UNESP, 1995. p. 114-124.

CERQUEIRA, L. Poluição do ar. Situação preocupante, porém controlada. Disponível em: www.unilivre.org.br. Acesso em: 2000.

CETESB - CIA TECNOLOGIA SANEAMENTO AMBIENTAL. Relatório de Qualidade do Ar no Estado de São Paulo - 2000. São Paulo: CETESB, 2001. 120p. Disponível em: www.cetesb.gov.br. Acesso em 04/10/2009

Relatório de qualidade do ar no Estado de São Paulo - 2002. São Paulo, 2003.120p. 
COELHO, A. P. Aspectos da poluição do ar e o meio ambiente brasileiro. SUPREN Superintendência de Recursos Naturais e Meio Ambiente. Recursos naturais, meio ambiente e poluição. Rio de Janeiro: F. IBGE, 1997. P. 155-169.

DERÍSIO, J. C. Introdução ao controle de poluição ambiental. 2 ed. São Paulo: Signus, 2000.164p.

EPA -ENVIRONMENTAL PROTECTION AGENCY. UNITED STATES GOVERNMENT. Electronic code of federal regulations: title $\mathbf{4 0}$ - protection of environment. Disponível em: <www.epa.gov>. Acesso em: 03/09/ 2009.

IBAMA. INSTITUTO BRASILEIRO MEIO AMBIENTE RECURSOS NATURAIS RENOVÁVEIS. Conselho Nacional de Meio Ambiente. Resolução №. . 03, de 28 de junho de 1990. Estabelece padrões de qualidade do ar. Brasília: CONAMA, 1990.

LIU, B. W. Y., FIORAVANTE, E. F. Monitoramento da qualidade do ar: Região metropolitana de Belo Horizonte, eixo Belo Horizonte-Contagem-Betim. Relatório Técnico. FEAM/DIQAR. Belo Horizonte, 2002. 27 p.

RIBEIRO, J. C. J. Indicadores Ambientais - avaliando a política de meio ambiente no Estado de Minas Gerais. Belo Horizonte. Secretaria de Estado de Meio Ambiente e Desenvolvimento Sustentável, 2006

RICCI, M. C.; LAURI J.; LIRIA, C. W.; BONETTO, N. C. F. Manual de metodologia do trabalho científico. Faculdades Oswaldo Cruz. São Paulo, 2006.

SECRETARIA MUNICIPAL DE MEIO AMBIENTE. Divisão de Licenciamento Ambiental. Banco de dados do automonitoramento da qualidade do ar. Microsoft Excell. Versão 2003. Betim, 2009.

WEHRHAN, R. Ecological Problems in Large Latin American Cities. Applied geography and development. Tübingen, v. 47, p. 48-70, 1996. 